\title{
PENGARUH KECEPATAN PUTAR DAN BEBAN TERHADAP KELUARAN GENERATOR INDUKSI 1 FASE KECEPATAN RENDAH
}

\author{
Agus Supardi, Aris Budiman, Nor Rahman Khairudin \\ Jurusan Teknik Elektro Fakultas Teknik Universitas Muhammadiyah Surakarta \\ Jl. A. Yani Tromol Pos 1 Pabelan Kartasura 57102 Telp 0271717417 \\ Email: Agus.Supardi@ums.ac.id
}

\begin{abstract}
ABSTRAKSI
Peningkatan permintaan energi telah mendorong pemanfaatan sumber energi terbarukan untuk membangkitkan energi listrik. Pada daerah - daerah terpencil di Indonesia sering kali tersimpan potensi energi yang dapat dimanfaatkan untuk membangkitkan energi listrik. Salah satu pilihan dalam pembangkitan energi listrik dalam skala kecil di daerah yang terisolir adalah dengan memanfaatkan generator induksi 1 fase sebagai alat konversi energinya. Makalah ini memaparkan pengaruh kecepatan putar dan beban terhadap keluaran generator induksi 1 fase kecepatan rendah.

Penelitian dimulai dengan merancang belitan stator generator induksi 1 fase dengan jumlah kutub sebanyak 12 buah. Stator generator induksi yang digunakan mempunyai 48 buah slot. Berdasarkan hasil perancangan tersebut kemudian dibuat prototipe generatornya. Setelah itu dilakukan serangkaian pengujian di laboratorium untuk mengetahui kinerjanya. Pengujian dimulai dengan mengkopel generator induksi dengan penggerak mula yang berupa motor listrik. Kapasitor eksitasi dan multimeter dihubungkan secara paralel pada terminal belitan stator. Generator induksi kemudian diputar hingga mencapai kecepatan tertentu dengan jalan mengatur regulator tegangan yang terhubung pada motor penggerak mula. Hasil penunjukkan tegangan dan frekuensi dicatat untuk pengujian dalam kondisi tanpa beban dan dalam kondisi berbeban.

Hasil penelitian menunjukkan adanya pengaruh kecepatan putar dan beban terhadap keluaran generator induksi kecepatan rendah. Semakin tinggi kecepatan putarnya maka semakin tinggi tegangan dan frekuensinya. Semakin besar bebannya maka semakin rendah tegangan dan frekuensinya. Dalam kondisi tanpa beban, generator yang diuji dapat membangkitkan tegangan sebesar 220 volt 83,9 Hz ketika dihubungkan dengan kapasitor sebesar 16 mikrofarad dan diputar pada kecepatan 850 rpm. Ketika kecepatan putarnya divariasi dari 525 - 850 rpm maka tegangannya akan bervariasi dari 65 - 220 volt dan frekuensinya akan bervariasi dari 52,1 - 83,9 Hz. Variasi pembebanan dari 5 - 15 watt dengan kecepatan putar dari 605 - 850 rpm akan menyebabkan tegangannya bervariasi dari 101 - 214 volt dan frekuensinya akan bervariasi dari $51,8-85 \mathrm{~Hz}$.
\end{abstract}

Kata kunci: generator induksi, 1 fase, kecepatan rendah

\section{PENDAHULUAN}

Energi listrik merupakan salah satu bentuk energi yang tidak bisa dipisahkan dalam kehidupan di era modern. Seiring waktu yang berjalan, kebutuhan energi terus meningkat sedangkan cadangan energi fosil semakin berkurang bahkan habis. Oleh karena itu diperlukan suatu upaya untuk memanfaatkan berbagai potensi energi terbarukan untuk memenuhi kebutuhan energi listrik dalam skala rumah tangga.

Indonesia sebagai salah satu negara kepulauan memiliki banyak pulau - pulau yang di dalamnya sering dijumpai potensi energi potensial air yang berupa aliran sungai atau air terjun. Pemanfaatan aliran air untuk membangkitkan energi listrik akan sangat membantu dalam memenuhi kebutuhan energi listrik di daerah - daerah terisolir yang belum terjangkau oleh jaringan listrik PLN. Aliran air tersebut dapat digunakan untuk menggerakan turbin air atau kincir air yang selanjutnya menjadi penggerak generator pembangkit listrik. Generator tersebut akan mengkonversikan energi potensial air menjadi energi listrik.

Generator induksi dapat digunakan untuk membangkitkan listrik dalam skala kecil. Generator induksi telah banyak dimanfaatkan di berbagai belahan dunia mulai dari skala penelitian sampai pemanfaatannya dalam suatu pembangkit listrik. Hadziselimovic et al (2013) mengungkapkan bahwa mesin induksi dapat dioperasikan sebagai generator maupun sebagai motor. Generator induksi merupakan mesin 
induksi yang difungsikan sebagai generator. Generator ini merupakan pilihan yang tepat untuk diterapkan di daerah terpencil. Hal itu disebabkan generator induksi dapat diterapkan dalam kondisi tanpa jaringan listrik (Gupta and Wadhwani, 2012), dapat beroperasi secara optimal dalam kondisi stand alone, mudah dioperasikan, dan mempunyai kinerja yang cukup baik dalam kondisi berbeban (Farraq and Putrus, 2014). Senthilkumar (2010) memaparkan bahwa generator induksi memiliki beberapa keunggulan yaitu murah, kuat, handal, tidak perlu sumber dc untuk eksitasi, sederhana konstruksinya, dan mudah perawatannya.

Kapasitor memiliki peranan yang sangat penting dalam aplikasi generator induksi. Thakur (2011) memaparkan bahwa kapasitor diperlukan oleh generator induksi dalam proses pembangkitkan tegangan. Kapasitor tersebut dihubungkan secara paralel pada terminal belitan stator. Kapasitor tersebut akan berlaku sebagai suatu eksitasi bagi generator induksi. Menurut Shilpa and Dias (2013) penggunaan kapasitor yang terhubung seri pada generator induksi akan menghasilkan tegangan yang konstan dalam kondisi tanpa beban. Rakgati and Setlhaolo (2011) menyatakan bahwa ukuran kapasitor akan mempengaruhi unjuk kerja generator induksi dalam kondisi tanpa beban maupun dalam kondisi berbeban.

Untuk aplikasi generator induksi dalam pembangkit listrik pikohidro dengan tinggi jatuh air (head) yang rendah, biasanya kecepatan putar yang dihasilkan oleh kincir airnya juga rendah. Dalam rangka meningkatkan kecepatan putar maka seringkali digunakan pully dan/atau gearbox dengan rasio tertentu. Pemakaian pully dan/atau gearbox akan menimbulkan rugi-rugi daya yang disebabkan oleh gaya gesekan antar komponennya sehingga efisiensi sistem pembangkit juga akan turun. Pemakaian pully dan/atau gearbox juga akan membuat sistem mekanik pembangkit menjadi lebih rumit, perawatannya menjadi lebih susah, biaya investasi dan biaya perawatannya juga menjadi lebih tinggi.

Dalam makalah ini akan dipaparkan karakteristik tegangan dan frekuensi generator induksi 1 fase kecepatan rendah yang dapat digunakan sebagai pembangkit listrik berkapasitas kecil dan tidak terhubung dengan jala-jala listrik (stand alone). Generator tersebut akan dieksitasi dengan menggunakan kapasitor yang dihubungkan secara paralel pada belitan utama.

\section{METODE PENELITIAN}

2.1 Bahan dan Peralatan yang digunakan Bahan dan peralatan yang digunakan dalam penelitian ini adalah :

a. Generator induksi 1 fase kecepatan rendah yang digunakan untuk membangkitkan listrik

b. Motor listrik yang digunakan untuk memutar generator induksi.

c. Voltage regulator untuk mengatur kecepatan putar motor listrik.

d. Sabuk ( $v$ belt $)$ yang digunakan untuk mengkopel generator induksi dengan motor penggerak mula.

e. Puli dengan rasio 2 : 1 yang digunakan untuk memasang sabuk transmisi mekanis.

f. Dudukan besi yang digunakan menopang generator induksi dan motor listrik penggerak mula.

g. Mur baut yang digunakan untuk mempertahankan posisi peralatan pada dudukan besi.

h. Tachometer yang digunakan untuk mengukur kecepatan putar generator induksi.

i. Multimeter digital yang digunakan untuk mengukur tegangan dan frekuensi generator induksi.

\subsection{Langkah-langkah Pengujian}

Langkah - langkah pengujian yang dilakukan untuk mengamati pengaruh kecepatan putar dan beban terhadap keluaran generator induksi 1 fase kecepatan rendah ditunjukkan dalam diagram alir pada gambar 1 . 

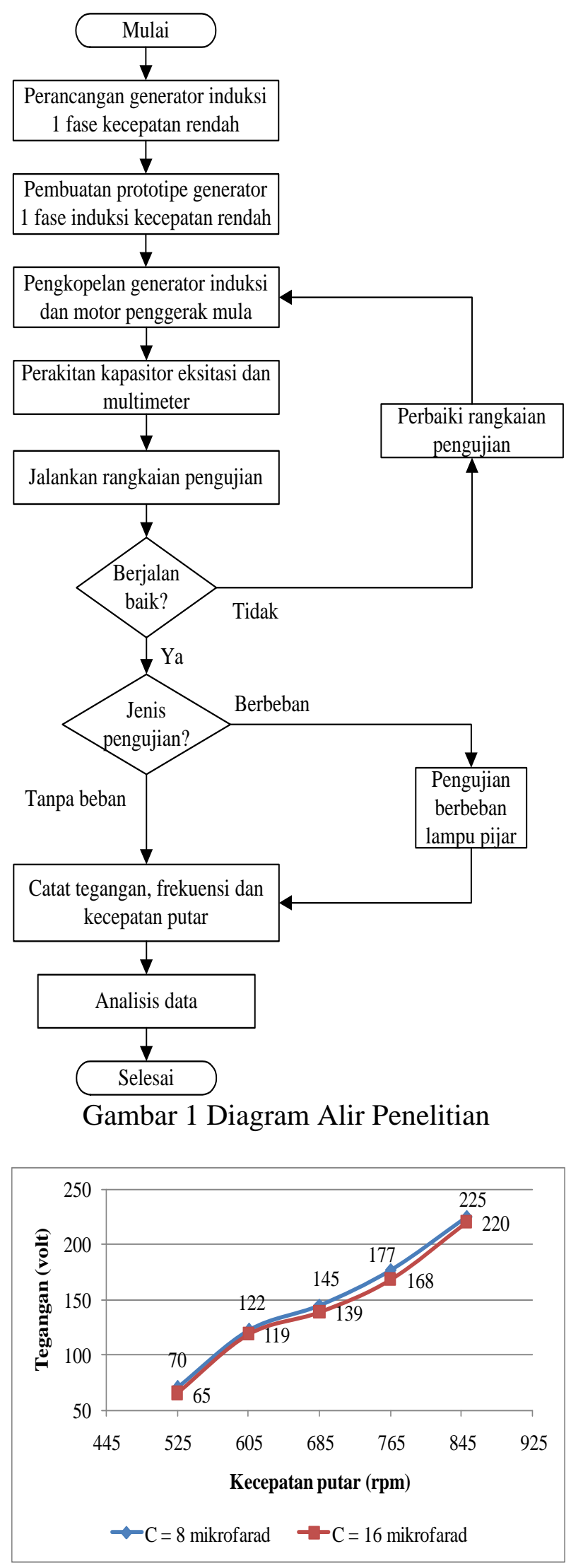

Gambar 2 Pengaruh kecepatan putar terhadap tegangan generator induksi kecepatan rendah dalam kondisi tanpa beban

\section{HASIL DAN PEMBAHASAN}

\subsection{Hasil Pengujian Generator Tanpa Beban}

Hasil pengujian generator induksi dalam kondisi tanpa beban ditunjukkan pada gambar 2 dan gambar 3. Ukuran kapasitor eksitasi yang dihubungkan adalah 8 dan 16 mikrofarad.

Gambar 2 menunjukkan adanya pengaruh kecepatan putar terhadap tegangan keluaran generator induksi kecepatan rendah dalam kondisi tanpa beban. Tegangan tersebut berubah hampir secara linier seiring dengan kenaikan kecepatan putarnya. Dalam pengujian ini, belitan stator generator induksinya didesain dengan jumlah kutub sebanyak 12 buah. Dengan demikian, secara teoritis kecepatan sinkron medan magnetnya adalah sebesar $500 \mathrm{rpm}$ dengan frekuensi sebesar $50 \mathrm{~Hz}$. Sehubungan generator yang diuji adalah jenis induksi maka akan terjadi slip antara kecepatan putar rotor dan kecepatan putar medan magnet statornya. Oleh karena itu, rotor generator induksi perlu diputar lebih besar dari $500 \mathrm{rpm}$. Hasil pengujian menunjukkan agar dapat menghasilkan tegangan sekitar 220 volt dalam kondisi tanpa beban maka rotor generator induksi harus diputar dengan kecepatan sekitar $850 \mathrm{rpm}$. Kecepatan putar ini jauh lebih tinggi dari kecepatan putar teoritisnya. Data juga menunjukkan ketika rotornya diputar di sekitar kecepatan sinkronnya (525 rpm) maka tegangan yang dibangkitkan hanya sekitar 65 volt. Hasil pengujian ini mengindikasikan bahwa generator induksi masih perlu disempurnakan desainnya yaitu terkait dengan desain belitan stator atau desain rotornya. Sehubungan generator induksi yang dipakai dari jenis sangkar tupai maka akan lebih mudah untuk memodifikasi desain statornya. Perubahan yang dapat dilakukan adalah dengan memperbanyak jumlah lilitan karena tegangan generator akan berbanding lurus dengan jumlah lilitannya. Perubahan ini dapat dilakukan dengan memperbesar atau tanpa memperbesar ukuran dari slot statornya. Bila ukuran slot stator dipertahankan tetap maka ukuran diameter lilitannya yang harus 
diperkecil. Hanya saja, dengan cara ini akan mengakibatkan resistansi dan reaktansi dari belitan stator akan naik sehingga akan berpengaruh terhadap kinerja dari generator induksi. Di sisi yang lain, dengan diameter yang semakin kecil maka arus yang diijinkan mengalir dalam lilitan juga akan semakin kecil. Hal ini berarti bahwa kapasitas / daya yang mampu dipasok dari generator nantinya juga akan turun.

Gambar 2 juga menunjukkan bahwa ukuran kapasitor akan berpengaruh terhadap tegangan keluaran generator induksi. Hal ini sejalan dengan hasil pengujian Rakgati (2011). Data menunjukkan dengan ukuran kapasitor yang lebih besar ternyata tegangan keluarannya justru menjadi lebih kecil. Untuk kecepatan putar sebesar $850 \mathrm{rpm}$ maka dengan menggunakan kapasitor sebesar 8 mikrofarad akan menghasilkan tegangan sebesar 225 volt. Ketika ukuran kapasitornya dinaikkan menjadi 16 mikrofarad maka tegangannya justru turun menjadi 220 volt. Kapasitor yang dipakai pada generator induksi akan berfungsi sebagai sumber eksitasi dalam proses pembangkitan medan magnet dalam generator induksi dengan menyediakan daya reaktif yang dibutuhkan oleh generator. Secara teoritis, daya reaktif yang harus disediakan oleh kapasitor harus disesuaikan dengan kebutuhan generator induksi. Bila suplai daya reaktifnya terlalu berlebihan maka kapasitor tersebut justru akan membebani generator induksi sehingga tegangan induksinya menjadi lebih kecil.

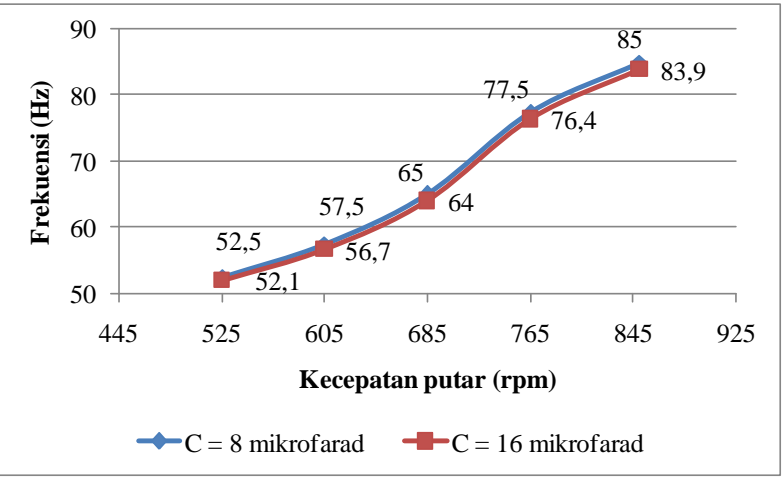

Gambar 3 Pengaruh kecepatan putar terhadap frekuensi generator induksi kecepatan rendah dalam kondisi tanpa beban.
Gambar 3 menujukkan adanya pengaruh kecepatan putar terhadap frekuensi generator induksi kecepatan rendah dalam kondisi berbeban. Frekuensi generator akan berubah secara proporsional seiring dengan kenaikan kecepatan putarnya. Hal ini sesuai dengan teori mesin listrik yang menyatakan bahwa kecepatan putar generator akan menentukan frekuensi generator. Semakin tinggi kecepatan putarnya maka semakin tinggi frekuensinya. Generator yang diuji adalah generator induksi 12 kutub, sehingga secara teoritis ketika generator diputar dengan kecepatan 500 rpm maka akan dihasilkan frekuensi sebesar $50 \mathrm{~Hz}$. Data pengujian menunjukkan bahwa ketika generator diputar pada kecepatan sekitar 525 rpm maka dihasilkan frekuensi sekitar $52 \mathrm{~Hz}$. Ketika kecepatan putarnya dinaikkan maka frekuensinya juga akan naik.

Gambar 3 juga menunjukkan bahwa ukuran kapasitor akan sedikit mempengaruhi frekuensi generator induksi. Untuk kecepatan putar yang sama, ukuran kapasitor yang lebih besar akan menyebabkan frekuensinya menjadi turun. Hasil ini mengindikasikan bahwa kapasitor yang dipakai selain berperan sebagai sumber eksitasi juga berperan sebagai beban. Hal ini diduga akibat dari ukuran kapasitor yang dipasang melebihi kebutuhannya sehingga berubah menjadi beban kapasitif.

\subsection{Hasil Pengujian Generator Dengan Beban Resistif}

Hasil pengujian generator induksi dalam kondisi berbeban yang berupa lampu pijar ditunjukkan pada gambar 4 dan gambar 5 .

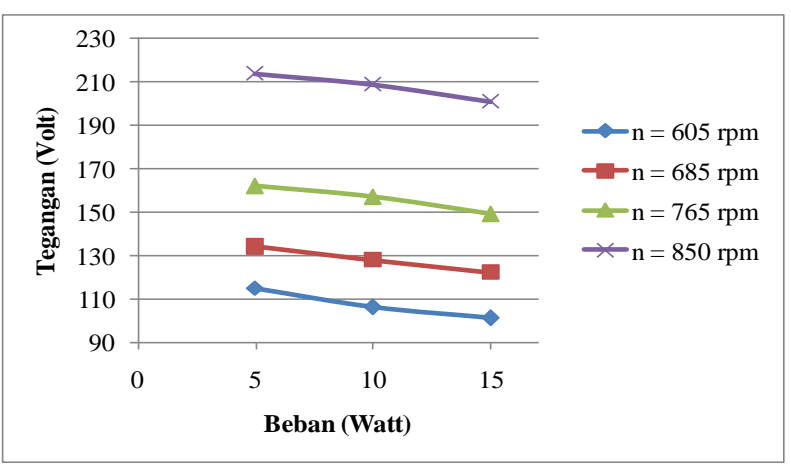


Gambar 4 Pengaruh beban resistif terhadap tegangan generator induksi kecepatan rendah

Gambar 4 menunjukkan adanya pengaruh beban terhadap tegangan generator induksi kecepatan rendah. Tegangan generator berbanding terbalik dengan daya beban. Semakin besar daya bebannya maka semakin kecil tegangan generatornya. Secara teoritis, ketika beban dihubungkan pada terminal generator induksi maka arus akan mulai mengalir pada belitan stator. Adanya resistansi dan reaktansi pada belitan stator akan mengakibatkan munculnya susut tegangan. Menurut Hukum Ohm, besarnya susut tegangan ini akan berbanding lurus dengan arus yang mengalir. Arus tersebut akan ditentukan oleh daya bebannya. Semakin besar daya bebannya maka semakin besar arus yang perlu disuplai ke beban tersebut. Dengan demikian, ketika beban dinaikkan maka susut tegangan akan semakin naik sehingga tegangan pada terminal generatornya akan menjadi semakin turun.

Gambar 4 juga menunjukkan bahwa tegangan generator induksi pada saat berbeban juga akan dipengaruhi oleh kecepatan putarnya. Data menunjukkan untuk daya beban yang sama maka semakin tinggi kecepatan putarnya akan menghasilkan tegangan yang semakin tinggi.

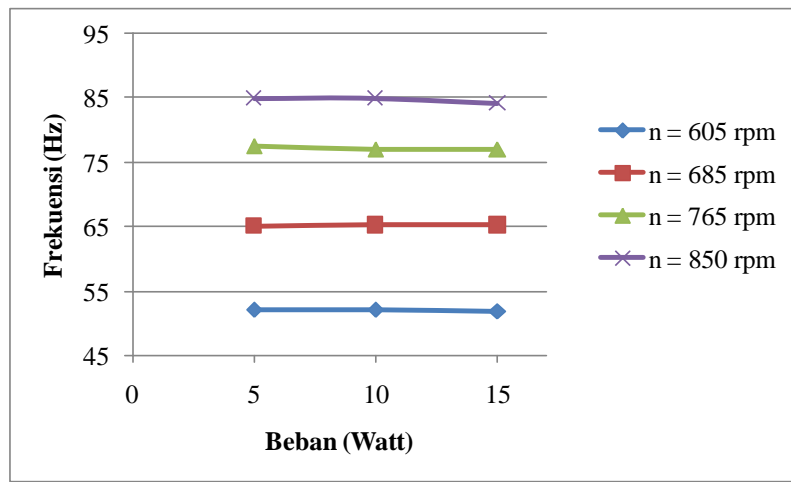

Gambar 5 Pengaruh beban resistif terhadap frekuensi generator induksi

Gambar 5 menunjukkan adanya pengaruh beban terhadap frekuensi generator induksi walaupun pengaruhnya cukup kecil. Kecilnya pengaruh beban ini diduga akibat dari kecilnya variasi daya beban yang dihubungkan pada terminal generator induksi. Data menunjukkan bahwa frekuensi generator akan berbanding terbalik dengan daya bebannya. Semakin besar daya bebannya maka semakin kecil frekuensinya. Secara teoritis, frekuensi generator akan ditentukan oleh kecepatan putarnya. Beban yang dihubungkan pada terminal generator induksi akan mempengaruhi kecepatan putar generatornya. Bila tenaga penggerak mula generator dipertahankan konstan ketika beban ditambah, maka kecepatan putar generatornya akan semakin turun seiring dengan kenaikan daya beban. Hal inilah yang memperkuat hasil pengujian terkait dengan fenomena penurunan frekuensi generator induksi ketika daya beban dinaikkan.

Gambar 5 juga menunjukkan bahwa frekuensi generator induksi pada saat berbeban juga dipengaruhi oleh kecepatan putarnya. Data menunjukkan untuk daya beban yang sama maka semakin tinggi kecepatan putarnya akan menghasilkan frekuensi yang semakin tinggi.

\section{KESIMPULAN}

Berdasarkan hasil penelitian dan pembahasan dapat ditarik kesimpulan sebagai berikut :

1. Kecepatan putar dan beban akan berpengaruh terhadap keluaran generator induksi 1 fase kecepatan rendah. Semakin tinggi kecepatan putarnya maka semakin tinggi tegangan dan frekuensinya. Semakin besar bebannya maka semakin rendah tegangan dan frekuensinya.

2. Dalam kondisi tanpa beban, generator yang diuji dapat membangkitkan tegangan sebesar 220 volt $83,9 \mathrm{~Hz}$ ketika dihubungkan dengan kapasitor sebesar 16 mikrofarad dan diputar pada kecepatan 850 rpm. Ketika kecepatan putarnya divariasi dari 525 - $850 \mathrm{rpm}$ maka tegangannya akan bervariasi dari $65-220$ volt dan frekuensinya akan bervariasi dari $52,1-83,9 \mathrm{~Hz}$.

3. Variasi pembebanan dari $5-15$ watt dengan kecepatan putar dari 605 - $850 \mathrm{rpm}$ akan menyebabkan tegangannya bervariasi dari 101 - 214 volt dan frekuensinya akan bervariasi dari $51,8-85 \mathrm{~Hz}$.

\section{UCAPAN TERIMA KASIH}


Ucapan terima kasih disampaikan kepada Kemenristek Dikti selaku penyandang dana penelitian hibah bersaing sehingga penelitian ini dapat dilaksanakan. Ucapan terima kasih juga disampaikan kepada Lembaga Penelitian dan
Pengabdian Masyarakat Universitas Muhammadiyah Surakarta yang telah memfasilitasi penyelenggaraan berbagai kegiatan terkait pelaksanaan penelitian ini.

\section{DAFTAR PUSTAKA}

Farrag, M. E. A., and Putrus, G. A., 2014, Analysis of the Dynamic Performance of Self-Excited Induction Generators Employed in Renewable Energy Generation, Energies, 7: 278 - 294

Gupta, A., and Wadhwani, S., 2012, Analysis of Self-Excited Induction Generator for Isolated System, International Journal of Computational Engineering Research (IJCER), 2(2): 353 358

Hadziselimovic, M., Zagradisnik, I., and Stumberger, B., 2013, Induction Machine: Comparison of Motor and Generator Characteristics, Acta Technica Jaurinensis, 6(1): 39-47

Rakgati, E. K., and Setlhaolo, D.A., 2011, Design and Loading Effects of a Capacitor Excited Induction Generator, International Journal of Energy Systems Computers and Control (IJeESCC), 2(1): 25 - 34

Senthilkumar, M., 2010, Optimal Capacitor for Maximum Output Power Tracking of Self Excited Induction Generator Using Fuzzy Logic Approach, International Journal on Computer Science and Engineering (IJCSE), 02(05): 1758-1762

Shilpa, G. K. and Dias, P. F., 2013, Stability of Voltage Using Different Control Strategies in Isolated Self Excited Induction Generator for Variable Speed Aplications, International Journal of Engineering Trends and Technology (IJEET), 4(3): 2366 - 2370

Thakur, K., 2011, A Reliable and Accurate Calculation of Excitation Capacitance Value for an Induction Generator Based on Interval Computation Technique, International Journal of Automation and Computing, 8(4): $429-436$ 